Perwira Journal of Economics and Business (PJEB)

E-ISSN : 2775-572X

Volume 1 Nomor 1

Februari 2021

\title{
PENGARUH LITERASI KEUANGAN DAN SELF-EFFICACY TERHADAP PERILAKU KEUANGAN
}

\author{
Anastasia Anggarkusuma Arofah ${ }^{1}$, Rani Kurniawati \\ Universitas Perwira Purbalingga \\ anastasiaanggar@unperba.ac.id
}

\begin{abstract}
Financial behavior has an important role for individuals, because it relates to the individual's ability to achieve predetermined goals. In managing finances, a person needs more than just financial literacy but must have confidence in his abilities. This attribute is known in the psychological literature as "self-efficacy". Using the survey on 150 senior high school students in Purbalingga Regency, financial literacy and self-efficacy being factor in affecting financial behavior. The result of research shows that financial literacy has a positive and significant contribution to financial behavior since the original sample value of 0.224 and the $t$-value of 2.420>1.96. Self-efficacy has a positive and significant contribution to financial behavior with an original sample value of 0.256 and a t-value of 3.251> 1.96. Students with high financial literacy have good financial behavior, and students with high self-efficacy will be better in managing their personal finances.
\end{abstract}

Keywords: Financial Literacy, Self-Efficacy, Financial Behavior

PENDAHULUAN

Masyarakat Ekonomi Asean (MEA) dalam bahasa Inggris dikenal dengan istilah AEC (Asean Economic Community) diberlakukan mulai tahun 2016. Masyarakat Ekonomi Asean (MEA) dirancang untuk mewujudkan Wawasan ASEAN 2020 yang beranggotakan Brunei, Filipina, Indonesia, Kamboja, Laos, Malaysia, Singapura, Thailand, dan Vietnam. Otoritas Jasa Keuangan (OJK) fokus pada peningkatan pemahaman masyarakat terkait keuangan karena jumlah masyarakat yang paham mengenai keuangan masih sedikit. Peningkatan literasi yang akhirnya merujuk pada perilaku keuangan ini penting untuk menghadapi Masyarakat Ekonomi Asean (MEA).

Perilaku keuangan memiliki peranan penting untuk individu karena berkaitan dengan kemampuan peserta didik untuk mencapai tujuan-tujuan yang telah ditetapkan. Perilaku keuangan dapat meningkatkan tanggung jawab pribadi dalam mengelola keuangan sehingga akan meningkatkan kesejahteraan pada masing- masing individu, dapat mencegah krisis keuangan di masa depan (Habschick, 2007; Sabri 2014). Namun pada kenyataanya, masih banyak individu yang mengalami masalah keuangan di masa depan. Beberapa diantaranya terjadi pada kalangan remaja. Di usia remaja, seseorang berada pada waktu yang sangat penting dalam kehidupan mereka dimana mereka menghadapi kemandirian finansial dan mulai melakukan pengambilan keputusan finansial yang bertanggung jawab.

Salah satu faktor yang diduga mampu mempengaruhi perilaku keuangan adalah literasi keuangan. Literasi keuangan berpengaruh signifikan terhadap perilaku keuangan (Sabri, 2014; Te'eni Harari, 2016). Literasi keuangan erat kaitannya dengan manajemen keuangan dimana semakin tinggi literasi keuangan seseorang maka semakin baik pula manajemen keuangan seseorang tersebut, begitu sebaliknya apabila literasi keuangan rendah maka individual tersebut akan mengalami masalah finansial (Lusardi \& Mitchell, 2014). Dengan demikian diduga bahwa literasi keuangan berpengaruh terhadap 
perilaku keuangan sehingga dihipotesiskan sebagai berikut.

H1: Literasi keuangan berpengaruh terhadap perilaku keuangan siswa

Selain literasi keuangan, perilaku keuangan dapat dipengaruhi oleh keyakinan diri seseorang atau biasa disebut dengan selfefficacy. Schuck (2012) menjelaskan selfefficacy bagi individu mengacu pada keyakinan terhadap kemampuan untuk belajar melakukan tindakan pada tingkatan yang ditentukan. Penelitian yang dilakukan oleh Farell et al. (2016) menyimpulkan bahwa self-efficacy memiliki peran positif bagi perilaku pengelolaan keuangan masyarakat di suatu negara. Dengan adanya self-efficacy, yang diterapkan ke dalam konteks pengelolaan keuangan pribadi, dapat diperkirakan bahwa individu yang memiliki rasa percaya diri lebih besar dalam kapasitas pengelolaan keuangan, maka individu tersebut cenderung mendekati kesulitan keuangan sebagai tantangan yang akan dihadapi bukan ancaman yang harus dihindari (Bandura, 2006). Dengan demikian diduga bahwa self-efficacy berpengaruh terhadap perilaku keuangan sehingga dihipotesiskan sebagai berikut.

H2: Self-efficacy berpengaruh terhadap perilaku keuangan siswa

Berdasarkan uraian diatas, maka penelitian ini dilakukan dengan tujuan untuk mengetahui pengaruh antara literasi keuangan dan self-efficacy terhadap perilaku keuangan pada siswa SMA di Kabupaten Purbalingga. Penelitian ini secara spesifik berbeda dengan penelitianpenelitian yang terdahulu karena menggabungkan kedua faktor yang mempengaruhi perilaku keuangan yaitu literasi keuangan dan self-efficacy. Selain itu, penelitian ini secara metodologis menggunakan analisis SEM (Stuctural Equation Modelling) yang secara jelas menggambarkan hubungan setiap indikator dalam variabel, sedangkan penelitian sebelumnya menggunakan analisis regresi linear berganda dan analyses of variance yaitu dengan melibatkan variabel faktor sebagai variabel pengendali dalam melakukan kajian dan sintesa terhadap temuan-temuan dalam penelitian.

\section{KAJIAN TEORI \\ Literasi Keuangan}

Literasi keuangan didefinisikan sebagai pengetahuan dan pemahaman seorang individu mengenai keuangan sehingga mampu mengelola keuangannya dengan baik. Variabel ini diukur menggunakan 9 item pernyataan yang diadaptasi dari OECD (2013b). Item pernyataan merupakan tanggapan responden tentang basic personal finance, money management, saving and investment.

\section{Self-efficacy}

Self-Efficacy mengacu pada keyakinan terhadap kemampuan untuk belajar melakukan tindakan pada tingkatan yang ditentukan berhubungan dengan keuangan. Variabel dari self-efficacy menurut Bandura (2006) antara lain: (a) magnitude, (b) strength, dan (c) generality. Variabel dari self-efficacy tersebut dijadikan indikator sebagai titik tolak untuk menyusun itemitem instrumen yang dapat berupa pernyataan atau pertanyaan.

\section{Perilaku Keuangan}

Perilaku keuangan adalah perilaku dalam mengelola keuangan pribadi dalam hal ini mengatur penggunaan uang saku yang diberikan orang tua dengan lebih bijak. Variabel ini diukur menggunakan 6 item pernyataan yang diadaptasi dari penelitian Dew \& Xiao (2011). Item pernyataan merupakan tanggapan responden tentang perencanaan keuangan, pengelolaan keuangan, dan pengendalian keuangan.

\section{METODE PENELITIAN}

\section{Desain Penelitian}

Penelitian ini merupakan penelitian kuantitatif explanatory dengan pendekatan survey cross sectional menggunakan angket karena tujuan utama penelitian ini adalah mendeskripsikan dan menginterpretasi objek sesuai dengan apa adanya dan 
membuktikan pengaruh antar variabel literasi keuangan dan self-efficacy terhadap perilaku keuangan siswa.

Dalam penelitian ini, terdapat 3 (tiga) variabel yaitu dua variabel bebas dan satu variabel terikat. Adapun kedua variabel bebas tersebut adalah literasi keuangan dan self-efficacy, sedangkan variabel terikatnya yakni perilaku keuangan. Desain model penelitian digambarkan dalam figure dibawah ini.

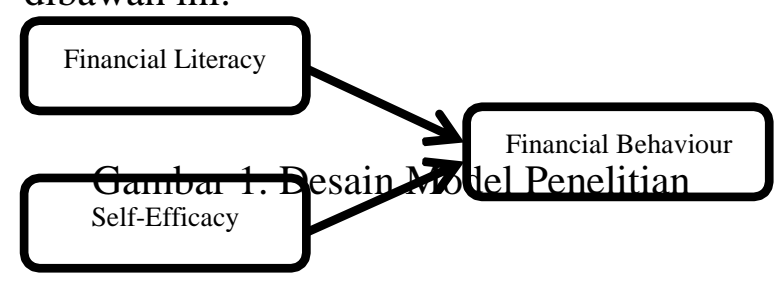

\section{Populasi dan Sampel}

Populasi dalam penelitian ini adalah semua siswa SMA Negeri di Kabupaten Purbalingga yang mempelajari ekonomi minimal satu tahun yang berjumlah 2640 siswa. Teknik pengambilan sampel dilakukan melalui proportional stratified random sampling dengan jumlah anggota sampel sebanyak 150 responden.

\section{Teknik Pengumpulan Data}

Penelitian ini menggunakan teknik pengumpulan data berupa kuesioner. Kuesioner penelitian ini menggunakan skala likert. Skala likert merupakan skala yang dapat digunakan oleh peneliti unutk mengukur sikap dalam suatu penelitian. Penggunaan skala Likert ada dua bentuk pernyataan yang biasa digunakan yaitu bentuk pernyataan positif dan bentuk pernyataan negative. Pernyataan positif digunakan untuk mengukur sikap positif, sedangkan pernyataan negatif untuk mengukur sikap negatif. Jawaban terdiri dari 4 pilihan yaitu Sangat Setuju (SS), Setuju (S), Tidak Setuju (TS), dan sangat Tidak Setuju (STS).

\section{Teknik Analis Data}

Teknik analisis data menggunakan analisis deskriptif dan analisis Structural Equation Modelling (SEM) dengan bantuan software SmartPLS 3.0. Langkah-langkah yang perlu dilakukan dalam menggunakan model persamaan struktural PLS sebagai berikut

(a) merancang model structural/ inner model, (b) merancang model pengukuran/outer model, (c) mengkontruksi diagram jalur, (d) konversi diagaram jalur ke dalam persamaan, (e) pendugaan parameter, (f) evaluasi kriteria goodness of fit, (g) pengujian hipotesis.

\section{HASIL PENELITIAN DAN PEMBAHASAN}

Penilaian responden merupakan hasil tabulasi kuesioner penelitian tercermin dalam tabel 1 . Tabel 1 berisi penilaian responden mengenai literasi keuangan, selfefficacy, dan perilaku keuangan. Dapat diketahui bahwa dari sampel 150 siswa Sekolah Menengah Atas Kabupaten Purbalingga sebanyak 67 siswa atau sebesar 44,67\% memiliki kecenderungan literasi keuangan dalam kategori tinggi. Angka tersebut menunjukkan persepsi responden yang tinggi terhadap literasi keuangan. Selain itu sebanyak 57 Siswa atau sebesar 38,00\% memiliki kecenderungan self-efficacy dalam kategori tinggi. Angka tersebut menunjukkan persepsi responden yang tinggi terhadap perilaku keuangan. Sebanyak 51 siswa atau sebesar 34,00\% memiliki kecenderungan perilaku keuangan dalam kategori tinggi. Angka tersebut menunjukkan persepsi responden yang tinggi terhadap perilaku keuangan. 
Tabel 1. Distribusi Kecenderungan Skor Literasi Keuangan

\begin{tabular}{cclcccccc}
\hline & & & \multicolumn{2}{c}{ Literasi Keuangan } & \multicolumn{2}{c}{ Self-Efficacy } & \multicolumn{2}{c}{ Perilaku Keuangan } \\
\hline No & Interval & Kategori & Frekuensi & Persentase & Frekuensi & Persentase & Frekuensi & Persentase \\
\hline 1 & $0-17$ & Sangat & 12 & 8,00 & 17 & 11,33 & 25 & 16,67 \\
& & rendah & & & & & & \\
2 & $18-22$ & Rendah & 45 & 30,00 & 42 & 28,00 & 48 & 32,00 \\
3 & $23-27$ & Tinggi & 67 & 44,67 & 57 & 38,00 & 51 & 34,00 \\
4 & $28-36$ & Sangat & 26 & 17,33 & 34 & 22,67 & 26 & 17,33 \\
& tinggi & & & & & & 100 & 150 \\
\hline
\end{tabular}

Sumber: data diolah, 2021

Selanjutnya untuk mengetahui pengaruh antara literasi keuangan dan sikap materialisme terhadap perilaku keuangan maka dikukan analisis data dengan menggunakan software SmartPLS 3.0. Tabel 2 dapat dijelaskan untuk melihat pengaruh antar variabel dapat dilihat

melalui nilai koefisien beta (original sample), sedangkan untuk mengetahui tingkat signifikasinya melalui $t$-statistic ( $t$ value). Nilai signifikasi yang digunakan adalah 1,96 dengan level signifikan sebesar $5 \%$.

Tabel 2. Total Effects

\begin{tabular}{lccccc}
\hline & $\begin{array}{c}\text { Original } \\
\text { Sample }(\mathbf{O})\end{array}$ & $\begin{array}{c}\text { Simple } \\
\text { Mean }(\mathbf{M})\end{array}$ & $\begin{array}{c}\text { Standard } \\
\text { Error } \\
\text { (STERR) }\end{array}$ & $\begin{array}{c}\text { T-Statistics } \\
\text { (O/STERR) }\end{array}$ & P-value \\
\hline Literasi->Perilaku & 0,224 & 0,234 & 0,165 & 2,420 & 0,024 \\
Literasi->Selfeffi & $\mathbf{0 , 2 1 8}$ & $\mathbf{0 , 3 2 7}$ & $\mathbf{0 , 1 1 0}$ & $\mathbf{2 , 7 5 7}$ & $\mathbf{0 , 0 0 3}$ \\
Selfeffi->Perilaku & 0,256 & 0,273 & 0,079 & 3,251 & 0,001 \\
Selfeffi->Literasi & $\mathbf{0 , 4 9 7}$ & $\mathbf{0 , 5 4 2}$ & $\mathbf{0 , 1 0 0}$ & $\mathbf{5 , 1 2 4}$ & $\mathbf{0 , 0 0 0}$ \\
\hline
\end{tabular}

Sumber: data diolah, 2021

Berdasarkan nilai koefisien beta (original sample) dan nilai $t$-statistic ( $t$-value) pada tabel 2, maka hasil uji untuk masingmasing hipotesis dapat dijelaskan sebagai berikut.

\section{Hipotesis 1}

Hipotesis menyatakan bahwa terdapat pengaruh yang signifikan antara literasi keuangan terhadap perilaku keuangan. Hasil pengujian hipotesis menunjukkan path antara variabel literasi keuangan dan perilaku keuangan memiliki nilai original sample 0,224 dan $t$-value $2,420>1,96$. Hasil ini menunjukkan bahwa variabel literasi keuangan berpengaruh positif dan signifikan terhadap perilaku keuangan, artinya hipotesis terbukti.

\section{Hipotesis 2}

Hipotesis menyatakan bahwa terdapat pengaruh yang signifikan antara self- efficacy terhadap perilaku keuangan. Hasil pengujian menunjukkan path antara variabel sikap materialisme dan perilaku keuangan memiliki nilai original sample 0,256 dan $t$-value $3,251>1,96$. Hasil menunjukkan bahwa variabel self-efficacy berpengaruh positif dan signifikan terhadap perilaku keuangan, artinya hipotesis terbukti.

\section{Pengaruh literasi keuangan terhadap perilaku keuangan}

Berdasarkan hasil pengujian, variabel literasi keuangan berpengaruh positif dan signifikan terhadap perilaku keuangan. Sifat prediksi positif (original sample 0,224) yang menunjukkan bahwa ketika literasi keuangan siswa tinggi, maka perilaku keuangan juga tinggi. Nilai parameter signifikansi tinggi sebesar 2,420 ( $t$-value $2,420>1,96)$ yang berarti bahwa literasi keuangan siswa secara signifikan 
memengaruhi perilaku keuangan. Kondisi ini ditunjukkan dengan pertama bahwa siswa merasa terbantu dalam mengelola keuangan pribadinya setelah memperoleh literasi keuangan berupa basic personal finance yang menyangkut pengetahuan mengenai pertimbangan manfaat barang dan jasa serta pengetahuan penentuan skala prioritas kebutuhan. Kedua, siswa merasa terbantu dalam merencanakan keuangan dan mengelola keuangan pribadinya setelah siswa memperoleh literasi keuangan berupa money management yang menyangkut pengetahuan mengenai perencanaan anggaran biaya dan pendapatan. Ketiga, siswa merasa terbantu dalam mengelola keuangan pribadinya setelah memperoleh literasi keuangan berupa saving investment yang menyangkut pengetahuan mengenai tabungan dan investasi, sehingga siswa dapat melakukan kegiatan menabung dan merencanakan dana untuk masa depan termasuk untuk pengeluaran kebutuhan yang tak terduga.

Berdasarkan hasil di atas, menunjukkan literasi keuangan yang dimiliki oleh siswa memberikan dampak yang optimal terhadap perilaku keuangan. Hasil penelitian menunjukkan pengaruh positif dan signifikan antara literasi keuangan dan perilaku keuangan sejalan dengan beberapa penelitian sebelumnya (Sabri, 2014; Morgan \& Long, 2020).

Literasi keuangan yang dimiliki oleh siswa ini dapat diperoleh melalui pendidikan keuangan. Pendidikan keuangan dalam keluarga dan pendidikan keuangan di sekolah akan memberikan efek positif pada anak (Sabri, 2014; Carlin Robinson, 2012). Dari hasil temuan penelitian ini, didapatkan cara untuk dapat meningkatkan perilaku keuangan yaitu dengan cara meningkatkan pendidikan keuangan baik di dalam lingkungan keluarga maupun lingkungan sekolah.

\section{Pengaruh self-efficacy terhadap perilaku keuangan}

Berdasarkan hasil pengujian, variabel selfefficacy berpengaruh positif dan signifikan terhadap perilaku keuangan. Sifat prediksi positif (original sample 0,256) yang menunjukkan bahwa ketika self-efficacy siswa tinggi, maka perilaku keuangan akan tinggi. Nilai parameter signifikansi tinggi sebesar 3,251 ( $t$-value 3,251 > 1,96) yang berarti bahwa self-efficacy siswa secara signifikan memengaruhi perilaku keuangan. Kondisi ini ditunjukkan dengan memiliki magnitude dimana ada siswa yang selalu optimis dalam menghadapi masalah keuangan akan memberikan keyakinan terhadap kemampuan yang dimiliki oleh siswa sehingga siswa mampu mengatasi masalah keuangan. Siswa memiliki strength dimana ada siswa yang merasa yakin atas kemampuan yang dimiliki akan memberikan keyakinan dalam mengelola keuangan sehingga siswa dapat mengelola keuangan dengan baik. Siswa memiliki generality dimana ada siswa yang merasa yakin atas kemampuan yang dimiliki memberikan keyakinan terhadap kemampuan siswa sehingga mampu mencapai keberhasilan kesejahteraan keuangan.

Berdasarkan hasil di atas, menunjukkan self-efficacy yang dimiliki oleh siswa memberikan dampak positif terhadap perilaku keuangan. Hasil penelitian ini sejalan penelitian beberapa penelitian sebelumnya yang menyatakan bahwa seseorang yang memilki self-efficacy akan berdampak pada perilaku keuangannya (Mayasari \& Sijabat, 2017; Qamar et al., 2016). Semakin tinggi self-efficacy seseorang maka perilaku keuangan atau mengelola keuangannya semakin baik. Hal ini dikarenakan self-efficacy merupakan salah satu aspek pskilogis yang dapat berupa keyakinan seseorang dalam mengeola keuangan. Sehingga pola pikir yang terbentuk adalah sesorang yakin akan berhasil dalam mengelola keuangan. 
Tingginya tingkat efikasi seseorang dalam melakukan pengelolaan keuangan, maka seseorang akan semakin bertanggungjawab dalam mengelola keuangan yang mana dari perilaku pengelolaan keuangan tersebut dapat membantu individu terhindar dari masalah keuangan

\section{SIMPULAN DAN SARAN}

Berdasarkan hasil penelitian di atas, maka dapat dipaparkan simpulan sebagai berikut. Pertama, literasi keuangan memiliki kontribusi yang positif dan signifikan terhadap perilaku keuangan. Hal ini dapat dilihat dari nilai nilai original sample 0,224 dan $t$-value $2,420>1,96$. Kedua, selfefficacy memiliki kontribusi positif dan signifikan terhadap perilaku keuangan dengan nilai nilai original sample 0,256 dan $t$-value 3,251 > 1,96. Siswa dengan tingkat literasi keuangan yang tinggi lebih mendidik perkembangan kompetensi pengelolaan keuangan. Kedua, peningkatan pendidikan keuangan di sekolah dapat dilakukan dengan pemberian sosialisasi dan seminar mengenai pengelolaan keuangan pribadi. Pemberian pendidikan pengelolaan keuangan dapat menghasilkan beberapa hal positif terkait dengan membelanjakan, menabung, dan menginvestasikan uang dengan benar.

\section{REKOMENDASI}

Hasil penelitian ini memberikan kontribusi untuk mengadakan penelitian selanjutnya

\section{DAFTAR PUSTAKA}

Bandura. (2006). Toward A Psychology of Human Agency. Perspectives on Psychological Science, 1(2), 164-180.

Carlin, B.I \& Robinson, D T. (2012). What Does Financial Literacy Teach Us? Journa of Economic Education, Taylor and Francis Journal, 43(3), 235-247.

Dew, J., \& Xiao, J. J. (2011). The Financial Management Behavior Scale: Development and validation. bisa mengelola keuangannya dengan baik, begitu juga dengan siswa yang memiliki self-efficacy yang rendah akan cenderung untuk dapat menahan keinginan dalam pembelian barang atau jasa.

Selanjutnya berdasarkan hasil penelitian ini disarankan beberapa hal terkait dengan perilaku keuangan siswa. Pertama, Peningkatan pendidikan keuangan di keluarga dapat dilakukan dengan cara melihat kembali orang-orang terdekat yang ada di sekitar lingkungan, lingkungan keluarga sebagai lingkungan terdekat hendaknya memberikan corak budaya, suasana rumah, pandangan hidup dan pola sosialisasi yang akan menentukan sikap dan perilaku. Selain itu orang tua bisa mensosialisasikan dan mendidik anak tentang keuangan dengan memberikan uang saku yang bisa menjadi sarana untuk

untuk menganalisis faktor-faktor yang lebih berperan dalam membentuk perilaku keuangan seperti status sosial ekonomi, lingkungan sosial, dan lainnya. Serta dapat memperluas cakupan populasi penelitian menjadi beberapa Perguruan Tinggi sehingga data yang dihasilkan lebih baik dan merata. Selain itu pendekatan penelitian kualitatif dapat dijadikan alternatif penelitian lanjut untuk melengkapi data kuantitatif yang dihasilkan dalam penelitian ini.

Journal of Financial Counseling and Planning, 22(1), 43-59.

Farrell, L., Fry, T. R. L., \& Risse, L. (2016). The Significance of Financial Self-Efficacy in Explaining Women's Personal Finance Behaviour. Journal of Economic Psychology, 54, 85-99.

Habshick. (2007). Survey of Financial Literacy Schemes in the EU27. Hamburg. Financial Services EVERS JUNG Research and Consulting.

Lusardi, A., \& Mitchell, O. S. (2014). The Economic Importance of Financial Literacy: Theory and Evidence. 
Journal of Economic Literature, 52(1), 5-44.

Mayasari, M., \& Sijabat, Z. M. (2017).

Pengaruh Financial Self-Efficacy

terhadap Perilaku Manajemen

Keuangan Individu. Journal of Applied Managerial Accounting.

Morgan, P. J. \& Long, T. Q. (2020). Financial literacy, financial inclusion, and savings behavior in Laos. Journal of Asian Economics, 101197.

OECD (Organisation for Economic Development and Cooperation). (2013b). PISA 2012 Assessment and Analitical Framework: Mathematics, Reading, Science, Problem Solving and Financial Literacy, Paris: OECD Publishing.

Qamar, M. A. J., Khemta, M. A. N., \& Jamil, H. (2016). How Knowledge and Financial Self-Efficacy Moderate the Relationship between Money Attitudes and Personal Financial Management Behavior. European Online Journal of Natural and Social Science, 5(2), 296-308.

Sabri, M. F, \& Tze Juen, T. (2014). The Influence of Financial Literacy, Saving Behaviour, and Financial Management on Retirement Confidence Among Women Working in the Malaysian Public Sector. Asian Social Science, 10(14), 40-51.

Te'eni-Harari, T. (2016). Financial Literacy Among Children: The Role of Involvement in Saving Money. Young Consumers, 17(2), 197-208.

Schunk, Dale. H. (2012). Learning Theories: An Educational Perspectives, 6th Edition. New York: Pearson Education Inc. 